\title{
IbM Pendampingan Pemanfaatan Ruang Sempit Menuju Lahan Produktif Melalui Sistem Pertanian Terintegrasi bagi Warga Pendrikan Kidul
}

\author{
Aries Jehan Tamamy ${ }^{1}$, Tita Talitha ${ }^{2}$, Pramudi Arsiwi ${ }^{3}$ \\ 1,2,3 Fakultas Teknik Universitas Dian Nuswantoro, Jl. Imam Bonjol 207 Semarang, \\ (024)-3517261 \\ e-mail: 1.jehantammy@dsn.dinus.ac.id,2 tita.talitha@dsn.dinus.ac.id, \\ pramudi.arsiwi@dsn.dinus.ac.id
}

\begin{abstract}
Abstrak
Tingkat kepadatan penduduk yang cenderung tinggi sejalan dengan proses pembangunan yang juga semakin cepat. Hal itu menyebabkan adanya perubahan pola penggunaan lahan, sehingga ruang - ruang alami terdesak karena beralih fungsi menjadi ruang terbangun seperti area pemukiman. Permasalahan tentang keterbatasan lahan sebagai ruang alami tersebut, dapat diselesaikan dengan menggunakan teknik bercocok tanam pada media terbatas seperti aquaponik. Metode ini dinilai tepat dikarenakan dapat disusun bertingkat/vertikal. Masalah yang dihadapi oleh warga Pendrikan Kidul adalah terkait dengan semakin sempitnya area terbuka hijau yang dapat dimanfaatkan sebagai lahan produktif. Berkurangnya lahan terbuka hijau diakibatkan lahan - lahan tersebut beralih fungsi menjadi rumah-rumah penduduk dan sebagainya. Selain itu juga adanya keterbatasan pengetahuan dari warga sekitar, yang belum memahami bagaimana inovasi dan terobosan yang dapat dilakukan untuk memanfaatkan lahan yang terbatas menjadi lahan produktif. Dari permasalahan tersebut, diharapkan dengan adanya metode pemanfaatan lahan sempit menggunakan sistem Aquaponic nantinya akan dapat meningkatkan daya inovasi, produktifitas dalam bidang pertanian, meningkatkan penghasilan, serta meningkatkan swasembada pangan bagi warga Pendrikan Kidul. Rencana pengabdian ini juga sekaligus mendukung program dari Pemerintah Kota Semarang yang disampaikan oleh Bapak Walikota, bahwa mulai Oktober 2018 hingga April 2019 mendatang akan diadakan lomba "Kampung Hebat", yang salah satu kategorinya adalah "Kampung Bersih dan Hijau.
\end{abstract}

Kata Kunci : Aquaponic, Green Campus, Pemanfaatan lahan, Pendrikan Kidul

\begin{abstract}
The level of population density which tends to be high is in line with the development process which is also getting faster. This causes a change in the pattern of land use, so that green open area are less because switching functions into built-up spaces such as residential areas. The problem about the limited land as a natural space, can be solved by using farming techniques in limited media such as aquaponics. This method is considered appropriate because it can be arranged in stages / vertical. The problem faced by Pendrikan Kidul residents is related to the increasingly narrow green open area that can be used as productive land. The reduction in green open land is caused by the land being converted into people's homes and so on. In addition, there is also limited knowledge of local residents, who have not yet understood how innovations and breakthroughs can be made to utilize limited land to become productive land. From these problems, it is expected that with the existence of a narrow land use method using the Aquaponic system, it will be able to increase the power of innovation, productivity in agriculture, increase income, and increase food self-sufficiency for citizens of Pendrikan Kidul. This service plan also supports the program from the Semarang City Government delivered by the Mayor that from October 2018 to April 2019 there will be a "Great Village" competition, one of which is "Clean and Green Villages
\end{abstract}

Keywords : Aquaponic, Green Campus, land utilization, Pendrikan Kidul 


\section{PENDAHULUAN}

Kota Semarang merupakan salah satu kota di Indoensia dengan tingkat kepadatan penduduk yang cukup tinggi. Menurut data dari Badan Pusat Statistik (BPS) pada tahun 2016, 5 dari total 17 wilayah dengan tingkat kepadatan penduduk tertinggi di Kota

Semarang adalah Semarang Selatam, Candisari, Gayamsari, Semarang Utara, dan Semarang Tengah. Wilayah Semarang Tengah dengan luas wilayah 6,14 km2 dihuni oleh 69.711 jiwa, sehingga tingkat kepadatannya mencapai 11.353 jiwa/km2 pada tahun 2016 [1]. Berdasarkan website profil Kecamatan Semarang Tengah, salah satu kelurahan yag cukup padat penduduknya dari total 15 Kelurahan di wilayah Semarang Tengah adalah Kelurahan Pendrikan Kidul [2].

Tingkat kepadatan penduduk yang cenderung tinggi sejalan dengan proses pembangunan yang juga semakin cepat. Hal itu menyebabkan adanya perubahan pola penggunaan lahan, sehingga ruang ruang alami terdesak karena beralih fungsi menjadi ruang terbangun seperti area pemukiman [3]. Permasalahan tentang keterbatasan lahan sebagai ruang alami tersebut, dapat diselesaikan dengan menggunakan teknik bercocok tanam pada media terbatas seperti hidroponik dan aquaponik. Kedua metode ini dinilai tepat dikarenakan dapat disusun bertingkat. Hidroponik tidak menggunakan media tanah, hal ini menyebabkan kurangnya nutrisi yang diperoleh secara alami sehingga memerlukan zat kimia untuk membantu pertumbuhannya. Sedangkan aquaponik memanfaatkan simbiosis mutualisme antara ikan dengan tanaman [4]. Feses ikan yang merupakan limbah berfungsi sebagai pupuk bagi tanaman. Sementara itu, tanaman berfungsi sebagai filter air bagi ikan, sehingga ikan mendapatkan suplai air bersih setelah kandungan limbahnya diserap oleh tanaman [5].

Adapun yang menjadi mitra dalam pengabdian masyarakat ini adalah warga Kelurahan Pendrikan Kidul yang terletak di Kecamatan Semarang Tengah, Kota

Semarang. Rencana pengabdian ini juga dalam rangka mendukung program dari Pemerintah Kota Semarang yang disampaikan oleh Bapak Walikota, bahwa mulai Oktober 2018 hingga April 2019 mendatang akan diadakan lomba "Kampung Hebat", yang salah satu kategorinya adalah "Kampung Bersih dan Hijau". Program Pemerintah Kota Semarang tersebut diadakan dengan tujuan memotivasi warga untuk ikut berkontribusi positif untuk kemajuan kampung masing-masing melalui aktivitas, inovasi, dan terobosan baru melalui program yang nyata [6]. Diharapkan dengan adanya program Pengabdian Masyarakat ini, nantinya dapat memberikan pemahaman dan pendampingan bagi warga Pendrikan Kidul, khususnya untuk melakukan inovasi dan terobosan baru dalam aspek pemanfaatan lahan sempit menjadi lahan produktif.

Masalah yang dihadapi oleh warga Pendrikan Kidul adalah terkait dengan semakin sempitnya area terbuka hijau yang dapat dimanfaatkan sebagai lahan produktif. Berkurangnya lahan terbuka hijau diakibatkan lahan - lahan tersebut beralih fungsi menjadi rumah-rumah penduduk dan sebagainya. Selain itu juga adanya keterbatasan pengetahuan dari warga sekitar, yang belum memahami bagaimana inovasi dan terobosan yang dapat dilakukan untuk memanfaatkan lahan yang terbatas menjadi lahan produktif.

Dari permasalahan tersebut, diharapkan dengan adanya metode pemanfaatan lahan sempit menggunakan sistem Aquaponic nantinya akan dapat meningkatkan daya inovasi, produktifitas dalam bidang pertanian, meningkatkan penghasilan, serta meningkatkan swasembada pangan bagi warga Pendrikan Kidul.

Berdasarkan analisis situasi dan permasalahan mitra yang telah disampaikan pada sub bab diatas, maka identifikasi masalah dapat dijelaskan seperti dibawah ini:

"Belum adanya pendampingan pemanfaatan ruang/lahan sempit menjadi lahan produktif melalui sistem pertanian terintegrasi menggunakan Aquaponic bagi Warga

Pendrikan Kidul”. 


\section{METODE PELAKSANAAN}

Dalam melaksanakan kegitan pelatihan dan pendampingan kepada masyarakat ini terdapat beberapa tahap yang dilakukan untuk dapat menangani permasalahan dengan terencana, runtun dan dapat berjalan dengan baik di Kelurahan Pendrikan Kidul. Beberapa proses tersebut adalah sebagai berikut:

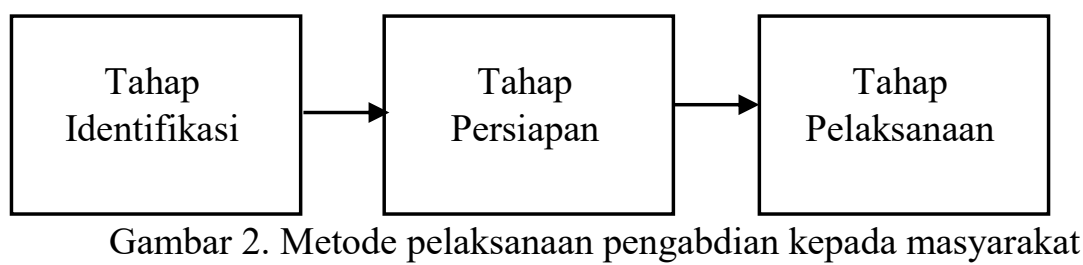

1. Tahap Identifikasi permasalahan dan perencanaan

Tahap identifikasi permasalahan dilakuakn dengan melekukan survey lapangan ke kelurahan Pendrikan Kidul dan juga beberapa rumah warga untuk mendapatkan data yang jelas tentang permasalahan lahan sempit dan pemanfaatannya di kelurahan pendrikan kidul. Setelah melakukan identifikasi masalah kemudian dilakukan koordinasi dengan Warga Pendrikan Kidul yang terdiri dari Kepala Kelurahan dan perwakilan warga yang tinggal di wilayah Pendrikan Kidul untuk menentukan jadwal, lokasi dan teknis pelaksanaan pengabdian.

Proses pengambilah data identifikasi dilakukan dengan melakukan wawancara kepada beberapa warga dan diskusi langsung dengan pihak kelurahan Pendrikan Kidul

\section{Tahap persiapan Kegiatan}

Beberapa proses persiapan kegiatan yang dilakukan antara lain pembuatan modul ajar pendampingan pemanfaatan ruang sempit melalui sistem Akuaponik dalam bentuk Power Point dan juga modul cetak yang akan dibagikan kepada peserta pelatihan. Dalam rangka memudahkan peserta pelatihan untuk dapat memahami cara kerja dan proses pembuatan sistem akuaponik, juga dipersiapkan sebuah rancangan sistem akuaponik sebagai model peraga dan praktik saat pelatihan. Setelah semua persiapan fisik selesai dilaksanakan, persiapan berikutnya yang dilakukan adalah melakukan persiapan administrasi dan penyebaran undangan untuk pelaksanaan pelatihan.

\section{Tahap Pelaksanaan pelatihan dan pendampingan}

Tahap pelaksanaan pelatihan dilakukan dengan dua tahap yaitu tahap presentasi dan pembekalan materi tentang pentingnya hasil pertanian organik bagi tubuh manusia serta materi tentang sistem akuaponik. Pembekalan materi ini dilakukan di kantor kelurahan pendrikan kidul yang dihadiri oleh beberapa kelompok kegiatan di kelurahan dan dilaksanakan dengan metode diskusi. Tahap berikutnya adalah pelatihan tentang cara kerja dan proses pembuatan sistem akuaponik yang dilaksanakan secara langsung dari proses awal sampai akhir dengan menggunakan modul sistem akuaponik yang telah disediakan.

\section{HASIL DAN PEMBAHASAN}

Pada Gambar 1 dapat dilihat proses Pengabdian kepada masyarakat Pendampingan Pemanfaatan Ruang Sempit Menuju Lahan Produktif Melalui Sistem Pertanian Terintegrasi bagi Warga Pendrikan Kidul telah berhasil mengadakan pelatihan dan pendampingan yang dilakukan di Kantor Kelurahan Pendrikan Kidul pada Hari Selasa, 12 Maret 2019 dengan memberikan dua pembekalan pengetahuan tentang pentingnya bahan makanan organic bagi tubuh manusia dan pengetahuan tentang system akuaponik. Untuk system akuaponik yang dipilih dalam pembekalan ini merupakan system akuaponik mini menggunakan pompa otomatis dan dapat dipasang di akuarium dalam rumah maupun di luar rumah. 


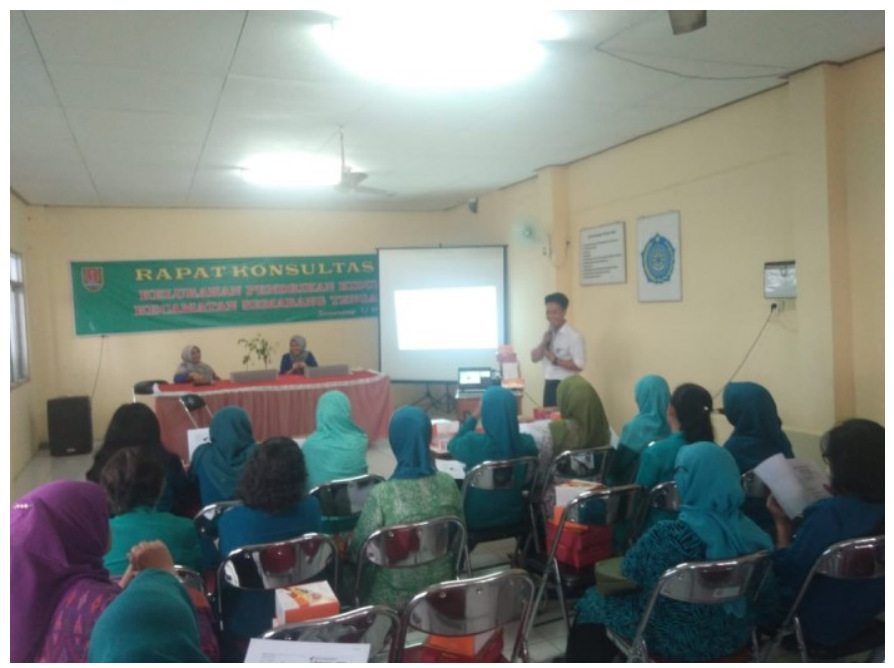

Gambar 2. Pembekalan Materi tentang bahan makan organik dan sistem akuaponik di kelurahan Pendrikan Kidul

Setelah melaksanakan pembekalan pengetahuan dilanjutkan dengan melakuan pelatihan pembuatan dan cara kerja sistem akuaponik kepada peserta pelatihan. Pada Gambar 2 dapat dilihat proses pelatihan yang dilakukan di kantor kelurahan pendrikan kidul. Pada tahap ini peserta diajak untuk membuat dan mempelajari sistem akuaponik secara langsung.
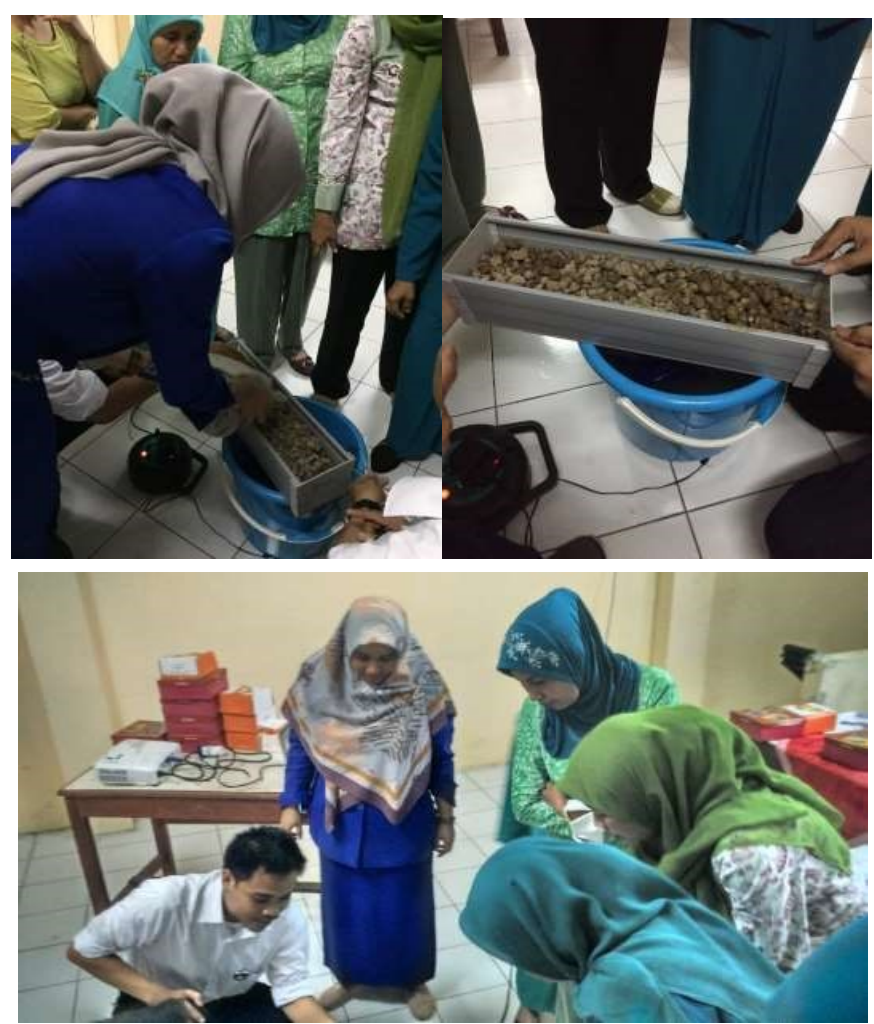

Gambar 3. Peserta melakukan pelatihan pembuatan sistem akuaponik

Kegiatan pengabdian kepada masyarakat ini dilanjutkan dengan melakukan pendampingan dalam pembuatan system akuaponik yang dilakukan di rumah warga Kelurahan Pendrikan Kidul. Proses pendampingan ini dilakukan sampai peserta dapat menerapkan ilmu yang dibagikan pada saat pelatihan seperti yang terlihat pada Gambar 3 . 


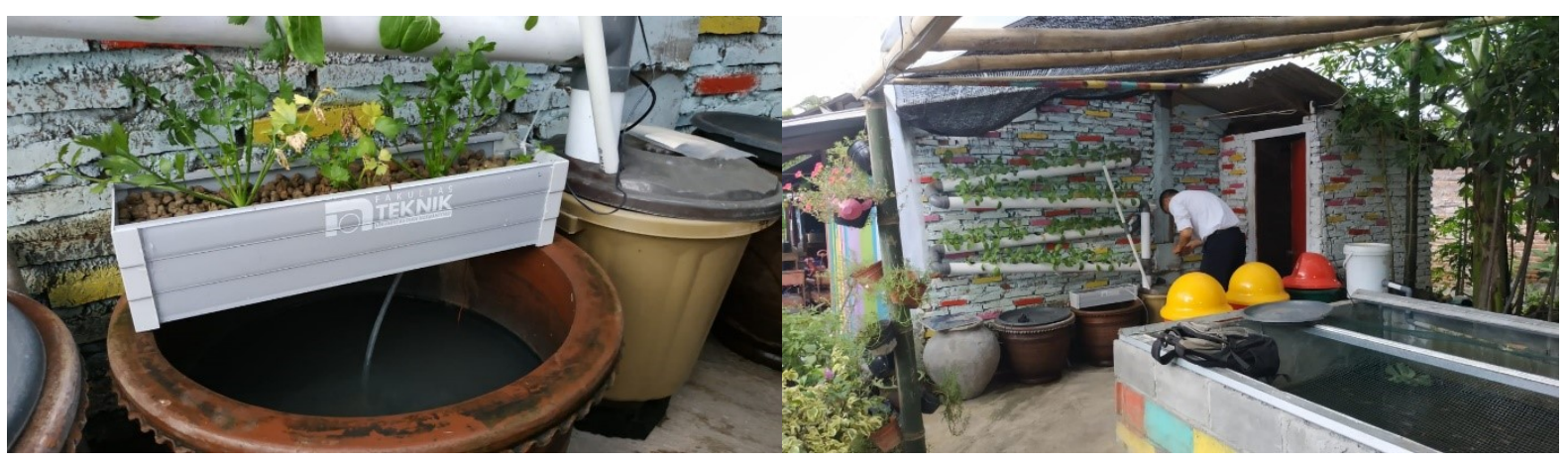

Gambar 4. Pendampingan dan pemasangan system akuaponik di rumah warga pendrikan kidul

Pada Gambar 4 dapat dilihat proses pemasangan dan pendampingan yang dilakukan di salah satu rumah warga Pendrikan Kidul. System akuaponik yang terpasang merupakan sebuah system otomatis dengan menggunakan sebuah pompa listrik dan dipasang pada gentong berisikan ikan lele sebagai bagian akuakulturnya.

\section{KESIMPULAN}

Setelah terlaksananya program pelatihan dan pendampingan yang dilakukan di kelurahan pendrikan kidul terdapat peningkatan pengetahuan peserta tentang pemanfaatan lahan sempit dengan menggunakan metode bercocok tanam akuaponik. Peserta pelatihan juga mampu membuat sistem akuaponik sederhana dengan memanfaatan alat dan bahan sederhana yang bisa didapatkan dari bahan bekas dan perkakas rumah. Selain itu peserta pelatihan juga dapat memahami pentingnya hasil budidaya pertanian, perkebunan dan perikanan organik untuk kesehatan.

\section{SARAN}

Untuk tahap pengabdian selanjutnya dapat ditingkatkan jumlah peserta dan durasi pelatihan serta pendampingannya. Selain itu juga dapat ditingkatkan dengan melakukan pendampingan dan pelatihan untuk sistem pemantauan otomatis untuk sistem akuaponik dengan menggunakan Internet of Things untuk tahap berikutnya.

\section{DAFTAR PUSTAKA}

[1] https://semarangkota.bps.go.id/dynamictable/2015/04/23/5/kepadatan-pendudukdikotasemarang-2012--2016.html, diakses tanggal 11 Oktober 2018

[2] https://kecsmgtengah.semarangkota.go.id/profil, diakses tanggal 11 Oktober 2018

[3] Mulqan, M., El Rahimi, S. A., \& Dewiyanti, I. (2017). Pertumbuhan dan Kelangsungan Hidup Benih Ikan Nila Gesit (Oreochromis niloticus) Pada Sistem Akuaponik Dengan Jenis Tanaman Yang Berbeda. Jurnal Ilmiah Mahasiswa Kelautan Perikanan Unsyiah, 2(1).

[4] Tulenan, Y.F.A., 2014, Perkembangan Jumlah Penduduk dan Luas Lahan Pertanian di Kabupaten Minahasa Selatan. E-Journal UNSTRAT, hal. 1 - 14.

[5] Zulhelman, Z., Ausha, H. A., \& Ulfa, R. M. 2017. PENGEMBANGAN SISTEM SMART AQUAPONIK. Poli-Teknologi, 15(2).

[6] https://radarsemarang.com/2018/08/07/kampung-hebat-lombakan-7-kategori/, diakses 11

Oktober 2018 